Вісник Дніпропетровського університету. Серія: геологія, географія. 24 (2), 2016, 111 - 119.

Vìsnik Dnìpropetrovs'kogo unìversitetu. Serìa Geologiâ, geographîa

Dnipropetrovsk University Bulletin. Series: geology, geography. 24 (2), 2016, 111 - 119.

Doi: $10.15421 / 111638$

http://geology-dnu.dp.ua

УДК 624.131.4

\title{
Зміни параметрів мікроструктури лесових грунтів під час фільтрації
}

\author{
К. О. Самойлич, Т. П. Мокрицька
}

\section{Дніпропетровський національний університет імені Олеся Гончара, Дніпро, Украӥна, kseniya.sam@таil.ru}

Підвищення рівня грунтових вод, передача постійних та тимчасових статичних та динамічних навантажень, зміна теплового режиму викликають зміни стану грунтового масиву, властивостей грунтів як у зоні повного водонасичення, так і в зоні аерації. Висока вразливість структурно-текстурних ознак грунтів в процесі техногенного впливу сприяє їх швидкій деградації (Mokritskaya, 2010). Процес деградації властивостей, структури та стану грунтів лежить в основі суфозійних, просадних та гравітаційних природно-техногенних явищ та потребує довивчення (Mokritskaya, 2013). Мета дослідження - визначення змін параметрів мікроструктури лесових грутів у результаті фільтрації. Об'єкт - еолово-делювіальні суглинки та супіски, відібрані у балці Євпаторійська (м. Дніпро). Предмет вплив фільтрації води на зміну мікроструктури грунтів. Результати досліджень показали, що найбільший винос частинок розміром $0,25-\mathbf{0 , 0 5}$ мм спостерігається в $\mathrm{eP}_{\text {II }}$ zV грунтах, переважно виносяться частинки тонкодрібнопіщаної фракції, які є своєрідною добавкою до крупнопилуватої фракції. Виявлено, що на параметри мікроструктури еолово-делювіальних відкладів фільтрація води крізь породу практично не вплинула, на відміну від елювіальних відкладів, які через більший вміст іонів $\mathrm{Ca}^{2+}$ (для $\mathrm{eP}_{\text {II }} \mathrm{ZV}$ він складає 0,6 ммоль/ 100 г грунту) здатні до більшого виносу частинок. Можливо, через те, що агрегатний спосіб підготовки відображас зміни у кількості водонестійких агрегатів, а вони не відбулись, фільтрація води через породу викликас більш складні перетворення мікростуктури, ніж просто винос частинок у нижчезалягаючі горизонти. Перебудова структури відбувається на іонному рівні і саме його відображають дисперсний та стандартний способи підготовки. Тож для виявлення зміни параметрів мікроструктури впродовж фільтрації доцільно використовувати методику “Мікроструктура". У результаті фільтрації протягом досліджуваного періоду зміна мікроструктури не відбулася, спостереження проводились до стабілізації винесених частинок, що дозволяс нам вважати ці результати правильними.

Ключові слова: агрегати, мікроструктура, трунти, фільтрація

\section{Change in the parameters the microstructure of loess soil during filtration}

\author{
K. O. Samoilych, T. P. Mokritskaya
}

Oles Honchar Dnipropetrovsk National University, Dnipropetrovsk, Ukraine, kseniya.sam@mail.ru

Increasing the level of groundwater of permanent and temporary transfer of static and dynamic loads, changing the thermal regime lead to changes in the state of the soil mass, soil properties as a complete water saturation zone and in the zone of aeration. The high vulnerability of structural and textural characteristics of soils in the man-made impact contributes to their the rapid degradation. Degradation of properties and structure of soil is the basis suffusion, subsidence and gravity of natural and industrial disasters and requires further tostudy (Mokritskaya, 2013). The purpose of research is to determine changes in the parameters of the microstructure of loess soils as a result of filtering. The object is aeolian and deluvian loams and sandy selected in the gully Yevpatorian (Dnipro). The subject is the effect of filtering water to change the microstructure of the soil. The results showed that the biggest removal particles of $0.25-0.05 \mathrm{~mm}$ observed in e $P_{I I} \mathbf{z v}$ soils, mostly fine particles are made of finely sand fraction, which is kind of addition to the large silty fractions. Revealed that the microstructure parameters aeolian-diluvial deposits filtering virtually no effect, unlike eluvial deposits, which due to larger content of ions $\mathrm{Ca}^{2+}$ (for e $P_{I I} \mathbf{Z v}$ it is $0.6 \mathrm{mmol} / 100 \mathrm{~g}$ soils) capable of greater particle transfer. Perhaps because the aggregate method of preparation reflects changes in the quantity of unstable water aggregates but it they are not took place, filtering water through rock leads to more complex transformations mikrostukture than just the removal of particles in the lower horizons bedding. The restructuring is to ionic levels and that it reflect the standard and dispersed methods of preparation. Therefore, to identify changes in microstructural parameters for filtering technique should be used "microstructure" (Ryaschenko, 2010). As a result of filtering during the period microstructure change did not take place, the observation was carried out to stabilize the rendered particles allows us to consider these results conditionally correct. Keywords: aggregates, microstructure, loess, filtration. 
Вступ. Підвищення рівня грунтових вод, передача постійних та тимчасових статичних та динамічних навантажень, зміна теплового режиму викликають зміни стану грунтового масиву, властивостей грунтів як у зоні повного водонасичення, так і в зоні аерації. Висока вразливість структурнотекстурних ознак грунтів у процесі техногенного впливу спричинює їх швидку деградацію (Mokritskaya, 2010). Під деградацією лесових грунтів розуміють «розлесування: ущільнення, втрату просадних властивостей, зникнення характерної текстури, вилуговування» (Krieger, 1965). Процес деградації властивостей, структури та стану грунтів лежить в основі суфозійних, просадних та гравітаційних природно-техногенних явищ та потребує подальшого вивчення (Mokritskaya, 2013). Мета досліджень - визначення змін параметрів мікроструктури лесових грунтів у результаті фільтрації. Об'єкт - вплив фільтрації води на зміну мікроструктури грунтів. Предмет - еоловоделювіальні суглинки та супіски, відібрані у балці Свпаторійська (м. Дніпро).

Матеріали та методика досліджень. Механізм руху води через дисперсну систему показано таким чином. Фільтрація води проходить перш за все по найбільш крупним порах, які не повністю зайняті зв'язаною водою. В порах меншого розміру за впливу градієнта напору проходить витискання частини порової води, що найменше міцно зв'язана зі стінками пор, через частково звільнений поровий простір відбувається фільтрація води. Через найменші пори фільтрація води практично не здійснюється, або ж дуже мала. (Goldberg, Skvortsov, 1986) За тривалого зволоження в лесових грунтах відбувається процес розчинення та виносу водорозчинних солей $\left(\mathrm{NaCl}, \mathrm{Na}_{2} \mathrm{SO}_{4}, \mathrm{CaCl}_{2}\right.$, $\mathrm{MgSO}_{4}, \mathrm{MgCl}_{2}, \mathrm{NaNO}_{3}, \mathrm{NaCO}_{3}$ ) (Kirillov, 1962).

Дисперсні грунти являють собою багатокомпонентні та багатофазні системи, складені мінеральними частинками, пори між якими заповнені повітрям та водою в різних видах та станах. Дисперсні утворення існують у природі завдяки наявності тонких міжфазних гідратних плівок на поверхні мінеральних частинок. Гідратні плівки зумовлюють специфічні властивості дисперсних систем, а саме, здатність до агрегування та диспергування, пластичність, набухання, стискання та ін. (Osipov, 2013). Усі дисперсні гірські породи складаються з частинок однієї або, частіше за все, декількох фракцій. В обмінних процесах грунтів переважно беруть участь катіони, вони перебувають у хімічному зв'язку з поверхневими молекулами мінеральних частинок. Кожна фракція має свою характерну для неї обмінну здатність: 0,25-0,005 мм, ємність обміну 0,3 ммоль/ 100 г грунту; 0,0050,001 мм, ємність обміну 15,0 ммоль/ 100 г грунту; 0,001 - 0,00025 мм, ємність обміну 37,2 ммоль/ 100 г грунту; 0,00025 мм, ємність обміну 69,9 ммоль/ 100 г грунту. Здатні до обміну катіони містяться на зовнішній поверхні частинок, у міжпакетному просторі кристалічної решітки.

У грунтах більш за все розповсюджені катіони $\mathrm{Ca}^{2+}, \mathrm{Mg}^{2+}, \mathrm{Na}^{+}, \mathrm{K}^{+}, \mathrm{H}^{+}, \mathrm{Al}^{3+}, \mathrm{Fe}^{3+}, \mathrm{Fe}^{2+}, \mathrm{NH}_{4}^{4+}, \mathrm{Li}^{+}$. Склад обмінних катіонів грає визначну роль у вмісті різноманітних категорій води у грунтах, одночасно впливаючи на формування його мікроструктури та мікротекстури. Утворення потужних оболонок зв'язаної води викликає розпад мікроагрегатів у грунтах. Зменшення оболонок зв'язаної води навколо грунтової частинки, навпаки, сприяє процесу коагуляції частинок, тобто створення мікроагрегатів, а це, у свою чергу, значно впливає на формування мікроструктури.

У присутності одновалентного катіона $\mathrm{Na}^{+}$за інших рівних умов частинки зв'язують значно більшу кількість води, ніж за присутності двовалентного катіона $\mathrm{Ca}^{2+} . \mathrm{Na}^{+}$-катіон підсилює вплив глинистих частинок на властивості породи, а двовалентні катіони, навпаки, цей вплив зменшують (Ananiev, 2005). Суттєве значення іонний обмін має під час формування іригаційно-грунтових вод за рахунок інфільтраційних за малих швидкостей фільтрації. Інфільтраційні води з рухом у порах порід зони аерації змінюють свою мінералізацію й іонно-сольовий склад за рахунок катіонного обміну за умов надходження на рівень грунтових вод. Такі ж процеси відбуваються в зоні підйому рівня грунтових вод у результаті значних фільтраційних втрат в умовах недостатнього дренажу. Особливо інтенсивно катіонний обмін відбувається в системі грунтовий розчин - тверда фаза - колоїдна фаза (Sherstiuk, 2005).

У зоні зволоження відбувається значна перебудова структури та зміна пористості грунтів. Вода, що надходить у лесові грунти по активних порах та тріщинах, послаблює та руйнує неводостійкі структурні зв'язки та мікроагрегати. При цьому різко зменшується капілярний тиск, що таким же чином послаблює зниження зчеплення між частинками грунтів. Одночасно відбувається руйнація неводостійких мезо- та мікроагрегатів, що складають основу неводостійкої системи лесових грунтів. У них зберігаються пилуваті та дрібнопіщані частинки та водостійкі мікроагрегати. Насичення грунтів водою спричинює швидку втрату структурного зчеплення та зниження кута внутрішнього тертя, розмокання та ущільнення (Voronkevich, 2005). 
Численними дослідженнями (Ф. Л. Андрухін, Ю. М. Абелев, А. М. Дранніков та ін.) установлено, що саме специфічна макропориста структура лесових грунтів і витягнутість капілярних каналів у вертикальному напрямку зумовлюють анізотропність різних властивостей макропористих лесових грунтів природної структури, і особливо фільтраційних властивостей. У вертикальному напрямку для лесів значення коефіцієнта фільтрації в 2,5 - 9 разів більше, ніж у горизонтальному. Для лесовидних суглинків коефіцієнт фільтрації у вертикальному напрямку перевищує коефіцієнт фільтрації в горизонтальному напрямку в 5 - 30 разів (Abelev, 1979; Balandin, 1984; Volohov, 1981; Grigirian, 1965; Zareckii, 1967; Kirillov, 1960, Levchenko, 2011). Складність проведення експериментальних досліджень для визначення характеристик проникності зумовлена тим, що багато видів макропористих лесових грунтів містять легкорозчинні солі. Крім того, під час руху води крізь шар лесових макропористих грунтів спостерігаються процеси суфозії. Суфозійні процеси в макропористих лесових грунтах спостерігаються за певних градієнтів напору, характерних для даного лесового грунту, і за певного часу руху води крізь грунт (Levchenko, 2011).

На підставі експериментальних досліджень в умовах тривісного стискання за різноманітних значень навантажень та напрямків фільтрації визначено інверсію фільтраційної анізотропії лесів порівняно з іï природним станом. Для лесових грунтів балок Тунельна та Тополина зафіксовано суфозію з невеликим процентом винесених частинок, найбільшу активність відмічено у перші години після початку фільтрації. Виявлено, що фракції 0,25 - 0,05 мм, 0,05-0,01 мм складають 3/4 від усього винесеного матеріалу. Відмічено також зміни макроструктури грунтів, які проявлялись в утворенні порушень, каверн, пустот, видимих зон розпушування. Цікавий висновок про те, що у досліджуваних грунтах має місце відрив агрегатів, а не частинок грунту (Sadovenko, Derevyahyna, 2013).

Водопроникність лесових грунтів Придніпров'я вивчали в рамках дослідження процесів іонного обміну та розчинення - осадження в багатокомпонентних водно-сольових системах в умовах техногенезу (Sherstiuk et al., 2005) за методикою (Bochever, 1979). Через складність виготовлення зразка природної потужності моделювання фізико-хімічних процесів проводили у зразках потужністю 0,2 м. (Sherstiuk and all, 2005). Завантаження грунту в циліндр проводили невеликими порціями для витіснення повітря, затисненого у порах породи. Насичення водою кімнатної температури відбувалось знизу догори. Після повного насичення грунту в циліндрі встановлювався постійний рівень води, який тримався на визначеній відмітці.

Досліджуючи іонно-сольовий обмін, переважні напрями руху, утворення пустот та суфозії, приділяли недостатню увагу змінам параметрів мікроструктури під час фільтрації води крізь породу. Зміни параметрів мікроструктури відображають зміни гранулометричного складу, від якого на пряму залежать гідрогеологічні властивості. Гранулометричний аналіз у складі порід враховує вміст у них первинних частинок, тобто вміст окремих уламків кристалів та гірських порід. У тонкодисперсних породах разом із первинними частинками присутні також вторинні, які утворились у процесі 3'єднання (злипання) декількох первинних частинок та формують мікроагрегати частинок. Кількість і розмір первинних частинок у грунтах визначає його первинна, або гранична, дисперсність. Вторинна, або природна, дисперсність, що характеризується мікроагрегатним складом, враховує в аналізі як первинні, так і вторинні частинки (Ananev, Potapov, 2005.). Гранулометричний склад характеризує граничну дисперсність, а мікроагрегатний відображає ступінь агрегування породи в даних умовах, використовуючи для характеристики структурні зв'язки у породі. Мікроагрегатний склад породи не постійний у часі, через постійне утворення у породі та руйнування вторинних частинок. Гранулометричний склад на даному відрізку часу є величиною постійною і змінюється тільки за впливу тривалих процесів.

На первинну дисперсність осадових порід значний вплив має їх мінералогічний склад. Чим вищий вміст глинистих мінералів у породі, тим вища іï дисперсність. Для досліджуваних грунтів виготовлені шліфи, за якими професор кафедри геології та розвідки покладів корисних копалин ДВНЗ НГУ М. В. Рузіна описала мінеральний склад. Еолово-делювіальні суглинки vd $\mathrm{P}_{\mathrm{II}}$ ts мають такий склад: кварц + плагіоклаз - $62 \%$; мікроклін - $7 \%$; біотит (гідратованнй) - 7 \%, серицит - $10 \%$, гідроокиси заліза + вуглисто-глиниста речовина $-5 \%$; уламкові агрегати карбонатного складу $-7 \%$. Форма уламків кутаста (переважає), рідко - напівобкатана. Розмір уламкових частинок варіюється від 0,005 мм до 0,06 мм (до 50 \%), одноразове скупчення (стяжіння) карбонату — до 0,6 мм.

У геоморфологічному відношенні досліджувана територія балки Свпаторійська розташована в межах терасованого вододільного схилу правого берега р. Дніпро, глибоко й інтенсивно порізаного яружно-балковою мережею; в південній частині міста, між балками Тунельною та Відлогою. Балка 
Євпаторійська сформована тривалими екзогенними процесами, початок яких належить до кінця неогену - початку четвертинного періоду. За класифікацією М.Ф. Веклича визначено, що досліджувані грунти належать до: тясминських еолово-делювіальних суглинків (vdP II $_{\text {ts), }}$ дніпровських еолово-делювіальних лесоподібних супісків $\left(\mathrm{vdP}_{\mathrm{II}} \mathrm{dn}\right)$ та завадівських елювіальних суглинків (eP II zv). У межах балки зафіксовано один водоносний комплекс, складений із двох водоносних горизонтів: четвертинного та неогенового. Водоносний горизонт четвертинних відкладів не витриманий за потужністю, коефіцієнт фільтрації грунтів зони аерації і водовмісних грунтів змінюється від 0,2 до 0,6 м/добу. Завадівські суглинки та суглинки і глини мартоноського горизонту $\epsilon$ відносно водонепрохідними шарами (Bogachenko, 2015). Режим водоносного горизонту порушений, живлення відбувається за рахунок інфільтрації атмосферних опадів, витоків із підземних комунікацій з боку мікрорайону «Сокіл», промислових підприємств та індивідуальної забудови вздовж лівого схилу балки. Розвантажується в дно балки, перетікає в нижній горизонт неогенових відкладів, а потім у р. Дніпро. За хімічним складом вода водоносного горизонту четвертинних лесових відкладів гідрокарбонатно-сульфатна 3 мінералізацією до 1 г/дм³. Між водоносними горизонтами відбувається перетікання шляхом вертикальної фільтрації. Геологічне вивчення ділянки досліджень показує, що від руйнації лесових прошарків від впливу атмосферних опадів не захищають вищезалягаючі прошарки глини, тож із часом матеріал виноситься.

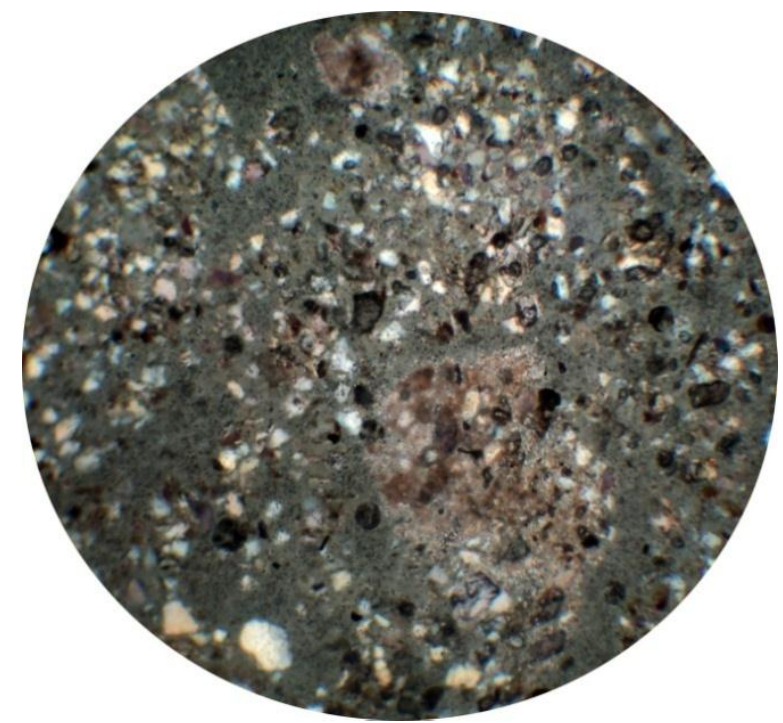

Рис. 1. Агрегатне скупчення карбонату, уламкові зерна кварцу та польового шпату, різнооріснтовані, мікролускуваті слюдисті мінерали. Світло прохідне, ніколі + зб.90. Зразок vd $\mathrm{P}_{\mathrm{II}} \mathrm{ts}$, балка Свпаторійська, 2016

У НДЛ геології, гідрогеології та геоінформатики в рамках експериментального визначення та прогнозу просадних властивостей (деградації) лесових грунтів завідувачка лабораторії Л.О. Носовою провела експериментальне визначення фільтраційних властивостей грунтів балки Євпаторійська за методикою (Bochever, Lapshin, Orodovskaya, 1979), що описувалась вище. Для аналізу використовували дистильовану воду. Аналіз проводився на трьох зразках грунтів, які моделювали процес фільтрації води у пластах, потужність кожного складала 0,2 м. Перед та після експерименту були відібрані зразки грунтів для визначення параметрів мікроструктури кожного з них та аналізу їх зміни у процесі фільтрації.

Визначення параметрів гранулометричного складу дисперсних лесових грунтів базуються на методі «Мікроструктура» (Ryaschenko, 2010). Для його реалізації проводять гранулометричний аналіз методом піпетки з трьома способами підготовки грунтів до нього: стандартний - згідно 3 чинним ДСТУ; дисперсний - руйнується максимальна кількість агрегатів, відбувається фізико-хімічне заміщення двовалентних катіонів кальцію та магнію, що входять до складу грунтів, на одновалентні катіони натрію; агрегатний - руйнуються тільки водонестійкі агрегати під час тривалого збовтування грунту 3 дистильованою водою протягом 2 годин на струшувачі. Саме ця підготовка ближче за все відображає руйнування агрегатів у природних умовах.

Відповідно до розміру за результатами аналізів, виділяють 6 типів агрегатів: середньокрупнопіщані $(1,00-0,25$ мм), тонкодрібнопіщані $(0,25-0,05$ мм), крупнопилуваті $(0,05-$ 
0,01 мм), дрібнопилуваті $(0,01-0,002$ мм), грубоглинисті $(0,002-0,001$ мм) та тонкоглинисті (<0,001 мм). Кількість агрегатів визначається за загальним вмістом агрегатів (сумою коефіцієнтів мікроагрегатності 3 від’ємним знаком). Коефіцієнт мікроагрегатності (К визначався як різниця між їх умістом за дисперсною та агрегатною підготовками. За ним можна оцінити ступінь агрегованості грунтів, визначити кількість та розмір агрегатів. Якщо К знаком, то вміст фракції відповідного розміру зменшується за рахунок руйнування цих агрегатів. Якщо $K_{\text {ма }} 3$ додатним знаком, то під час руйнування вивільнились частинки меншого розміру та склали «прибавку» відповідній фракції, що може викликати зміни фізичних та фізико-механічних властивостей. Ця методика, на відміну від стандартної, враховує такі зміни. Залежно від кількості агрегатів виділяються скелетний $(\mathrm{A} \leq 10)$, агреговано-скелетний $(10<\mathrm{A} \leq 25)$, скелетно-агрегований $(25<\mathrm{A} \leq 40)$ та агрегований $(\mathrm{A}>40)$ тип мікроструктури. Тип структурної моделі визначається за двома показниками: розміром структурних елементів, які переважають та коефіцієнтом елементарності, що показує частку первинних частинок у загальній сумі структурних елементів.

Результати та їх аналіз. Нижче показано результат зміни гранулометричного складу за різних підготовок для грунтів природного стану та після експериментального визначення фільтраційних параметрів для еолово-делювіального тясминського супіску (рис. 2 а, б). Після фільтрації за дисперсної підготовки перерозподілився вміст фракцій розміром 0,05-0,001 мм, за агрегатної практично нічого не змінилось, а за стандартної - зменшилась кількість фракцій $0,05-0,01$ мм, натомість збільшилась кількість фракції 0,1-0,001 мм. Можливо, через те, що агрегатний спосіб підготовки відображає зміни у кількості водонестійких агрегатів, а вони не відбулись, то скоріш за все фільтрація води через породу зумовлює більш складні перетворення мікроструктури, ніж просто винос частинок у нижчезалягаючі горизонти. Перебудова структури відбувається на іонному рівні i саме його змогли відобразити дисперсний та стандартний способи підготовки.

За всіх підготовок збільшився вміст фракції розміром $0,005-0,002$ мм. Найбільший вміст глинистих частинок розміром $<0,002$ мм виділяється за дисперсної підготовки грунтів до гранулометричного аналізу, найменший - за агрегатної. За дисперсної підготовки також видно, що під час фільтраційних досліджень зменшилась кількість глинистих частинок у всіх зразках. Після фільтрації протягом 7 діб зникли агрегати розміром $0,25-0,05$ мм, кількість яких у природних умовах складала 7,22 \%. Натомість утричі збільшилась кількість агрегатів розміром 0,05-0,01 мм з 8,6 до $24,86 \%$, та утворилась незначна кількість агрегатів розміром $0,01-0,002$ мм.

Розподіл гранулометричного складу vd P II ts до фільтрації

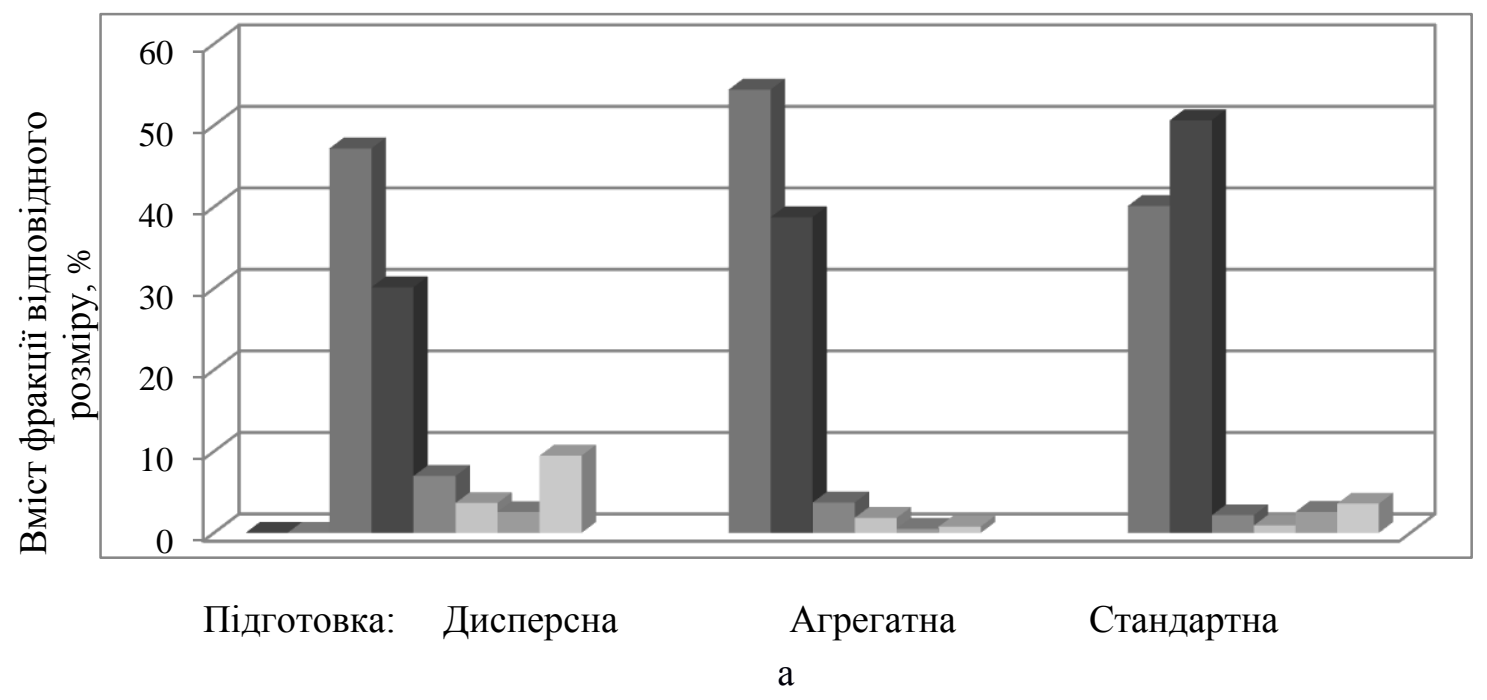




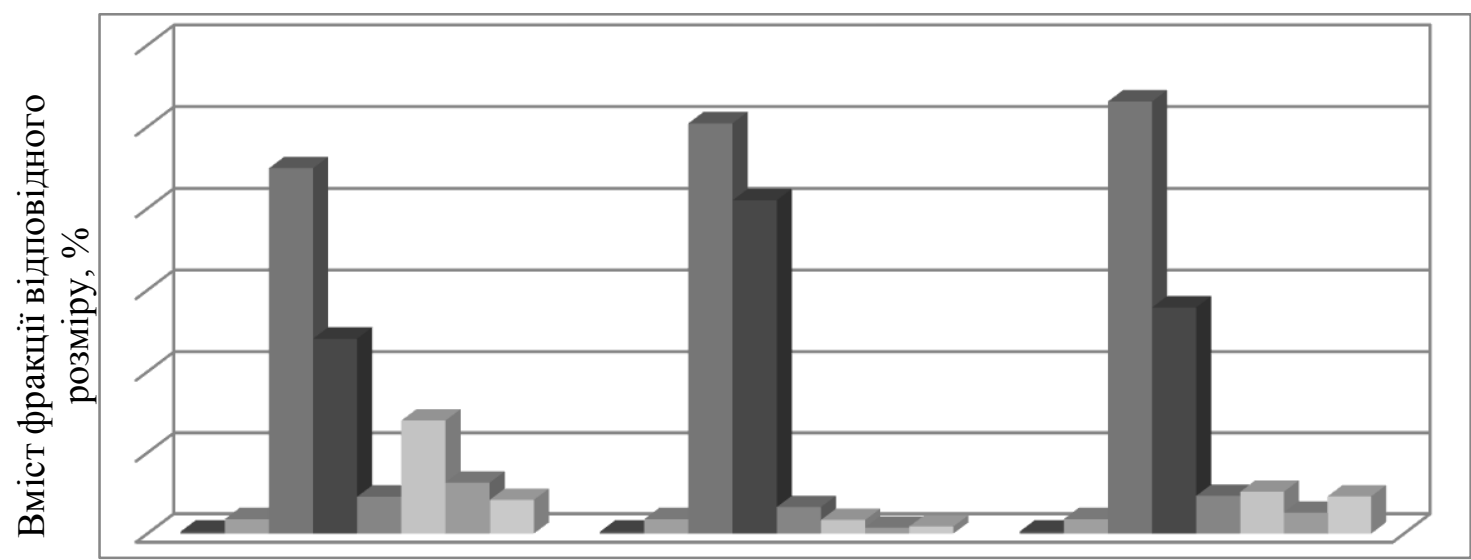

Підготовка: Дисперсна

Агрегатна Стандартна

б

Рис. 2 - Розподіл гранулометричного складу тясминського еолово-делювіального супіску: а - природного стану; б після експериментального визначення фільтраційних параметрів протягом 7 діб

Таблиия

Параметри мікроструктури досліджуваних зразків

\begin{tabular}{|c|c|c|c|c|c|c|}
\hline Стратиграфічний тип грунтів & \multicolumn{2}{|c|}{$\mathrm{vd} \mathrm{P}_{\mathrm{II}} \mathrm{ts}$} & \multicolumn{2}{|c|}{$\mathrm{vd} \mathrm{P}_{\mathrm{II}} \mathrm{dn}$} & \multicolumn{2}{|c|}{ e $P_{I I} Z V$} \\
\hline Глибина відбору, м & \multicolumn{2}{|c|}{4,0} & \multicolumn{2}{|c|}{5,0} & \multicolumn{2}{|c|}{6,0} \\
\hline Параметри мікроструктури & $\begin{array}{l}\text { Природний } \\
\text { стан }\end{array}$ & Фільтрація & $\begin{array}{c}\text { Природний } \\
\text { стан }\end{array}$ & Фільтрація & $\begin{array}{l}\text { Природний } \\
\text { стан }\end{array}$ & Фільтрація \\
\hline Тип мікроструктури & \multicolumn{2}{|c|}{ агреговано-скелетна } & \multicolumn{2}{|c|}{ скелетно-агрегована } & \multicolumn{2}{|c|}{ скелетно-агрегована } \\
\hline Тип структурної моделі & \multicolumn{2}{|c|}{$\begin{array}{c}\text { тонко-дрібнопіщана } \\
\text { елементарна }\end{array}$} & \multicolumn{2}{|c|}{$\begin{array}{l}\text { крупнопилувата } \\
\text { змішана }\end{array}$} & \multicolumn{2}{|c|}{$\begin{array}{l}\text { крупнопилувата } \\
\text { змішана }\end{array}$} \\
\hline Загальна кількість агрегатів, \% & 16,9 & 22,44 & 29,04 & 31,08 & 34,74 & 38,58 \\
\hline \multirow{2}{*}{$\begin{array}{c}\text { Переважаючий } \\
\text { розмір агрегатів, \% }\end{array}$} & 7,3 & 5,51 & 1,84 & 2,8 & 7,56 & 11,36 \\
\hline & 7,81 & 16,96 & 24,86 & 28,88 & 26,91 & 27,07 \\
\hline $\begin{array}{l}\text { Вміст первинних тонкодрібнопіщаних } \\
\text { частинок } \\
0,25-0,05 \text { мм, \% }\end{array}$ & 50,09 & 44,92 & 41,17 & 32,73 & 30,11 & 7,47 \\
\hline $\begin{array}{l}\text { Вміст первинних крупнопилуватих } \\
\text { частинок } 0,05-0,01 \mathrm{mм}, \%\end{array}$ & 28,56 & 24,04 & 25,78 & 22,55 & 28,35 & 23,5 \\
\hline 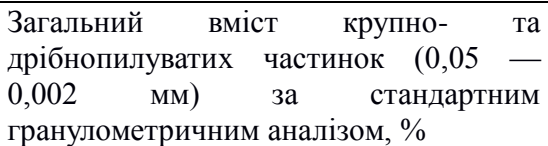 & 52,55 & 37,71 & 58,14 & 48,24 & 77,05 & 45,69 \\
\hline Реальна глинистість, \% & 12,89 & 10,45 & 20,23 & 12,64 & 31,34 & 17,6 \\
\hline
\end{tabular}

У результаті експериментального визначення фільтраційних параметрів відбулись такі зміни у мікроструктурі грунтів: типи структурної моделі та мікроструктури залишились незмінними; збільшилась загальна кількість агрегатів; відбулись незначні зміни у відсотковому вмісті середньокрупнопіщаної та тонкодрібнопіщаної фракцій, які переважно складають агрегати; вміст первинних тонкодрібнопіщаних частинок $(0,25-0,05$ мм) зменшився на $10 \%$ в еолово-делювіальних грунтах, та на понад $20 \%$ в елювіальних; загальний вміст крупно- та дрібнопилуватих частинок $(0,05$ 
- 0,002 мм) зменшився приблизно на $10 \%$ в еолово-делювіальних грунтах та приблизно на $30 \%$ в елювіальних. Тож найбільший винос частинок розміром $0,25-0,05$ мм спостерігається в $\mathrm{eP}_{\mathrm{II}} \mathrm{zV}$ грунтах, переважно виносяться частинки тонкодрібнопіщаної фракції, які є своєрідною добавкою до крупнопилуватої фракції (рис. 3, 4).

\section{Вміст частинок відповідного розміру, \%}

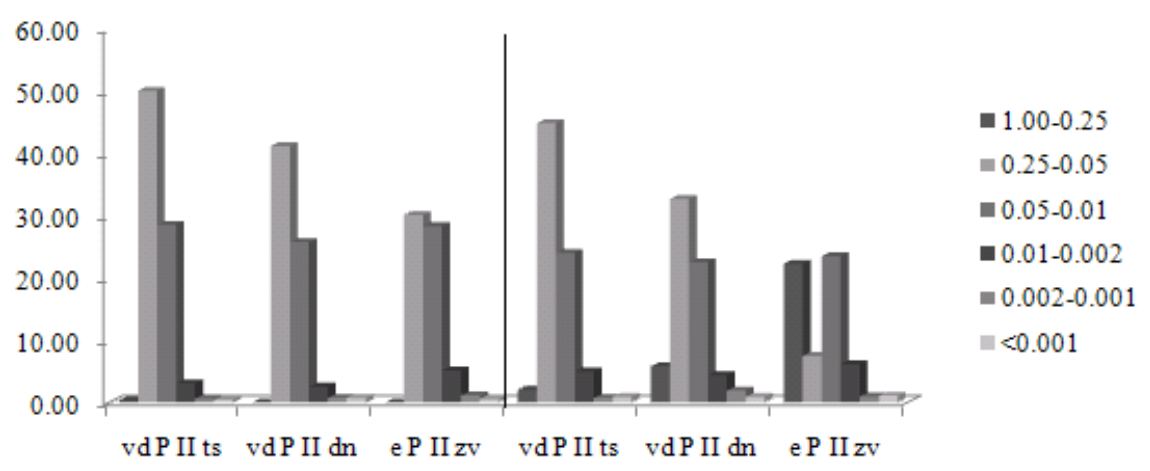

Природний стан - Після фільтрації

Рис. 3. Вміст частинок відповідного розміру грунтів vd $P_{\text {II }}$ ts, $v d P_{\text {II }} d n$, e $P_{\text {II }} z v$ у природному стані та після експериментального визначення фільтраційних параметрів, \%

\section{Вміст агрегатів відповідного розміру, \%}

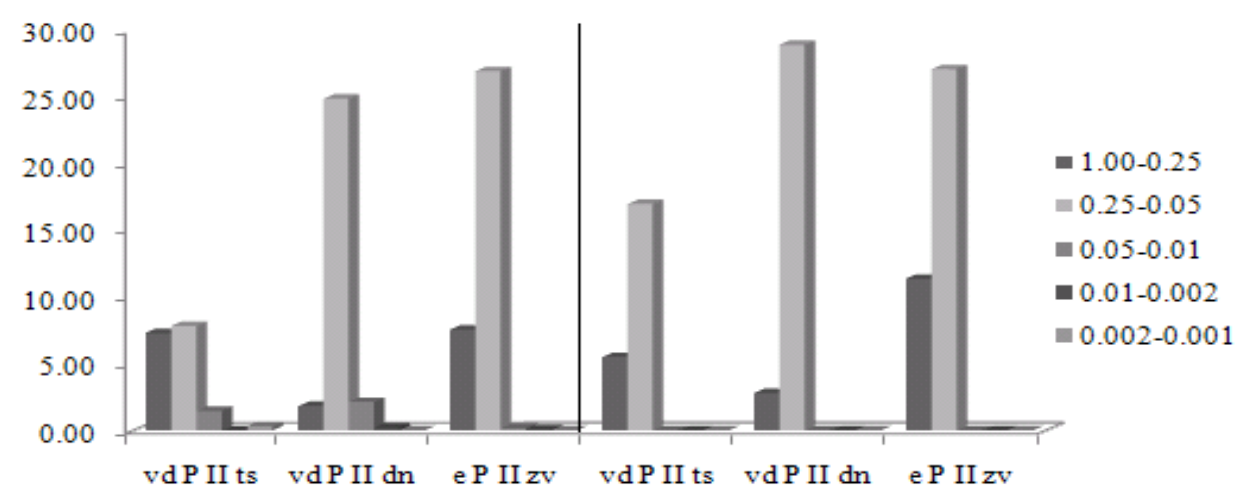

\section{Природний стан - Після фільтрації}

Рис. 4. Кількість агрегатів відповідного розміру грунтів vd $P_{\text {II }}$ ts, $v_{d P} \operatorname{dn}$, e $P_{\text {II }}$ zv y природному стані та після експериментального визначення фільтраційних параметрів, \%

Тож на параметри мікроструктури еолово-делювіальних відкладів фільтрація практично не вплинула, на відміну від елювіальних відкладів, що може бути наслідком того, що грунти, які мають більший вміст іонів $\mathrm{Ca}^{2+}$ (за результатами хімічного аналізу грунтів його вміст в $\mathrm{eP}$ II $\mathrm{ZV}$ складає 0,6 ммоль/ 100 г грунту, що удвічі більше за вміст $\mathrm{Ca}^{2+}$ в еолово-делювіальних грунтах), здатні до більшого виносу частинок.

Висновки. Виявлено, що на параметри мікроструктури еолово-делювіальних відкладів фільтрація практично не вплинула, на відміну від елювіальних відкладів, які завдяки більшому вмісту іонів $\mathrm{Ca}^{2+}$ (за результатами хімічного аналізу для е $\mathrm{P}_{\mathrm{II}} \mathrm{ZV}$ він складає 0,6 ммоль/ 100 г грунту)' здатні до більшого виносу частинок. Можливо, через те, що агрегатний спосіб підготовки відображає зміни у кількості водонестійких агрегатів, а вони не відбулись, фільтрація води через породу викликає більш складні перетворення мікроструктури, ніж просто винос частинок у нижчезалягаючі горизонти. Перебудова структури відбувається на іонному рівні і саме його відображають дисперсний та стандартний способи підготовки. Тож для виявлення зміни параметрів мікроструктури впродовж фільтрації доцільно використовувати методику «Мікроструктура». У результаті фільтрації протягом 
досліджуваного періоду тип мікроструктури не змінився, спостереження проводились до стабілізації винесених частинок, що дозволяє нам вважати ці результати правильними.

\section{Бібліографічні посилання}

Abelev Yu., Abelev M., 1979. Osnovi proektyrovanyya y stroytel'stva na prosadochnikh hruntakh. [Basics of designing and constructing on subsiding soils.] M. : Stroyizdat (in Russian).

Ananev, V., Potapov, A., 2005. Inzhenernaya geologiya: Ucheb. dlya stroit. spets. vuzov [Engineering geology : Proc . for the building . specialist. universities] M: Higherwksc (in Russian)

Balandyn, Yu.,, 1984. Fyzyko-mekhanycheskoe sostoyanye lessovikh porod kak kryteryy klassyfytsyrovanyya [Physical and mechanical condition of loess rocks like Crete-ries classification // Classification criteria for dividing the loess in the genus.] M. : Nauka (in Russian).

Bochever, F., Lapshin, N., Orodovskaya, A., 1979. Zashchyta podzemnikh vod ot zahryaznenyya [Protection of groundwater against pollution]. L .: Nedra (in Russian).

Bogachenko, L., Osadcha, L., Prokopenko, T., Sibul, T., 2015. Monitorynh zemel' ta stanu heolohichnoho seredovyshcha balky yevpatoriys'koyi (Dnipropetrovs'k) [Monitoring land that will geological environment of the gually Evpatoriyska (Dnipropetrovs'k) Vysnik Dnipropetrovskogo University. Seriya: Geologiya. Geografiya, 23 (1). 17 - 23 doi: 10.15421-111502 (in Ukrainian).

Goldberg, V., Skvortsov, N., 1986. Pronytsaemost' y fyl'tratsyya v hlynakh [The permeability and filtration in clays] M. : Nedra (in Russian).

Hryhoryan, A., Kulachenok, B., 1965. Polevie yssledovanyya deformatsyy prosadochnoho hrunta pod opitnimy shtampamy [Field studies deformations millet-sedimentary soil under the experimental stamps]. Grounds, foundations and soil mechanics. № 3 (in Russian).

Krieger, N., 1965. Less, eho svoystva y svyaz' s heohrafycheskoy sredoy. [Lesse, its properties and the connection with the geographical environment]. M.: Nauka (in Russian).

Kyryllov, A., 1962. Yssledovanye uplotnyaemosty lessovikh hruntov pry dal'neyshey fyl'tratsyy cherez nykh vodi [Research sealability loess soil at dalneysheyfiltratsii through them water // Engineering geological properties of rocks and methods ihizucheniya]. M. : Publishing House of the USSR Academy of Sciences (in Russian).

Kyryllov, A., 1960. Vlyyanye dlytel'noy fyl'tratsyy na uplotnyaemost' lëssovikh hruntov [Effect of long-term filtration compressibility loess soi] Scientific Notes. T. XXIII / MIIVH them. Williams. M. : Kolos (in Russian).

Levchenko, A., 2011. Otchet o nauchno-yssledovatel'skoy rabote osobennosty vzaymodeystvyya osnovanyy $\mathrm{y}$ fundamentov na lessovikh prosadochnikh hruntakh, $\mathrm{v}$ uslovyyakh nasishchenyya tekhnolohycheskymy y bitovimy stochnimy vodamy [Report on the research work of the peculiarities of interaction of the foundations on loess subsiding soils, in terms of technological and sanitary sewage saturation.] Innovation SEC "Engineer" (in Russian).

Mokritskaya, T., 2010. K voprosu o modelyakh prostranstvennoho raspredelenyya pokazateley svoystv hruntov horodskykh terrytoryy. [On the question of indicators of patterns of spatial distribution of soil properties in urban areas]. Bulletin DNU. Series: Geology. Geography, t.18, 84 - 91 (in Russian).

Mokritskaya, T., 2013. Formyrovanye y evolyutsyya heolohycheskoy sredi Prydneprovskoho promishlennoho rehyona. [Formation and evolution of geological environment Pridneprovsk industrial region]. Dnipropetrovsk, Accent PP (in Russian).

Osypov, V. Y., 2013. Fyzyko-khymycheskaya teoryya effektyvnikh napryazhenyy v hruntakh [Physicochemical theory of effective stress in soils] St. Petersburg Publishing House of the Center for Genetic Soil - № 2. 3- 35 (in Russian)

Ryaschenko, T., 2010. Regionalnoe Gruntovedenie (Vostochnaya Sibir) [Regional Soil (Eastern Siberia)] Irkutsk: Earth Crust SBRAS (in Russian).

Sadovenko, Y., Derevyahyna, N., 2013. Yssledovanye mekhanyzma formyrovanyya erozyonnikh deformatsyy lessovikh porod [Investigation of the mechanism of formation of erosive deformation of loess rocks] Naukovi pratsi UkrNDMI National Academy of Sciences of Ukraine, number 13 (Chastina I), Transactions of UkrNDMI NAN Ukraine, № 13 (part I), 2013 p. 339 - 345 (in Russian).

Sherstuk N.P. and all., 2005. Zvit pro naukovo-doslidnu robotu doslidzhennya protsesiv ionnogo obminu ta rozcynennya - osadzhennya $\mathrm{v}$ bahatokomponentnih vodno-sol'ovykh systemah $\mathrm{v}$ umovah 
tekhnogenezu. [Report on scientific research studies of ion exchange and dissolution - precipitation in multicomponent water-salt system in technogenesis] DNU, Dnipropetrvsk (in Ukrainian).

Volokhov, V., 1981. Ratsyonal'nie sposobi uplotnenyya lessovikh hruntov zamachyvanyem [Rational methods of sealing loess soils soak] Hydraulic engineering and reclamation . № 12 (in Russian).

Voronkevych, S.D., 2005. Osnovi tekhnycheskoy melyoratsyy hruntov [Fundamentals of technical reclamation of soils.] M. : Science World (in Russian).

Zaretskyy, Yu., 1967. Teoryya konsolydatsyy hruntov [The theory of soil consolidation.] M. : Nauka, 1967 (in Russian).

Надійшла до редколегії 24.10.2016 